\title{
Biological control in ornamental plants: from basic to applied knowledge
}

\author{
Brígida Souza (D) and Rosangela Cristina Marucci
}

Universidade Federal de Lavras, Escola de Ciências Agrárias, Departamento de Entomologia, Lavras-MG, Brazil

\begin{abstract}
Biological control is a worldwide trend and has been prominent as an effective and compatible strategy for use in Integrated Pest Management programs. In Brazil, the control of these organisms using biological agents has been used in several agricultural systems, including floriculture. This paper approaches biological control from the perspective of the interaction between organisms in nature, applied as a pest management strategy. Knowledge about the dependence and reciprocity among populations in a natural environment is fundamental to understanding that this control method is nothing more than an exploiting of a natural ecological service. Considering that, for the biological control of a pest we must increase the population density of natural enemies, we report on the two main ways to achieve this increase: conservative biological control and augmentative biological control. The first is done by modifying the environment's vegetation structure to favor natural enemies' maintenance or their attraction to the crops. The second is done by mass rearing entomophagous and entomopathogen species with attributes that can ensure their function as control agents when released in crops. Among such agents, we emphasize those produced and marketed in Brazil for application in ornamental plants. Finally, we report on the technologies most recently employed to increase the appropriate use and the efficiency of these biological control agents.
\end{abstract}

Keywords: Natural enemies, Integrated Pest Management, floriculture, technological innovations

\section{Resumo}

Controle Biológico em plantas ornamentais: do conhecimento básico ao aplicado.

O controle biológico é uma tendência mundial e tem se destacado como uma estratégia eficaz e compatível para uso em programas de Manejo Integrado de Pragas. No Brasil, o controle desses organismos, envolvendo agentes biológicos, tem sido utilizado em diversos sistemas agrícolas, inclusive, na floricultura. Neste artigo, o controle biológico é abordado sob o ponto de vista natural, por meio da interação entre os organismos na natureza, e aplicado, como estratégia para o manejo de pragas. O conhecimento sobre a dependência e reciprocidade existentes entre as populações na natureza é fundamental para a conscientização de que esse método de controle consiste na exploração de um serviço ecológico natural. Tendo-se em vista que, para o controle biológico de uma praga, a densidade populacional dos inimigos naturais deve ser aumentada, relatamos sobre as duas principais formas para se atingir esse incremento: o controle biológico conservativo e controle biológico aumentativo. A primeira, por meio da modificação do ambiente de cultivo de modo a oferecer uma estrutura vegetacional que favoreça a manutenção e/ou atração dos inimigos naturais, e a segunda, por meio da criação massal de entomófagos e entomopatógenos com características que possam garantir sua função como agentes de controle por ocasião da sua liberação nos cultivos. Entre tais agentes, enfatizamos aqueles que são produzidos e comercializados no Brasil para aplicação em plantas ornamentais. Por fim, relatamos sobre as tecnologias que têm sido mais recentemente empregadas para incrementar o uso adequado e a eficiência desses agentes biocontroladores.

Palavras-chave: Inimigos naturais, Manejo integrado de pragas, floricultura, inovações tecnológicas

\footnotetext{
*Corresponding author: brgsouza@ufla.br
} 


\section{Introduction}

Biological control occurs naturally and continuously in the most diverse ecosystems on the planet. It is a fundamental component of regulating populations of living beings through their natural enemies, mortality biotic agents. This balance in the population density of organisms in nature is based on a reciprocal density mechanism. In other words, the increase in the population of a species leads to an increase in the populations of secondary consumers due to the greater food availability. Consequently, the increase in the number of these mortality agents will negatively impact the primary consumers, thus beginning a new cycle again and again.

Secondary consumers, therefore, perform a vital ecological service to ecosystems as it involves the action of certain species, known as control agents or natural enemies. These agents act in regulating the populations of their victims, whether they are animals or plants. For example, colonies of aphids soon appear and their populations increase rapidly in rose cultivations installed in previously uncultivated areas. This rosebush-aphid association favors the attraction of the phytophagous insect's natural enemies, such as ladybugs and lacewings, whose larvae are aphidophagous. They will promote the reduction in the number of aphids. However, one must consider that all organisms have their range of natural enemies in nature. Thus, organisms that act naturally in regulating the pests population also have their populations controlled by natural enemies. Closing this cycle, decomposers, such as fungi, bacteria, and many insects and other invertebrates, obtain their food from dead animals and plants and through the decomposition of waste from other animals, being responsible for the return of part of the nutrients used by plants.

The results of numerous researches show the wide diversity of species with the potential to be used as control agents (Souza et al., 2019b). These evidences are based on these organisms' ability to interfere in pest arthropods' population dynamics and reduce their populations to remain below the control level.

Biological agents can act differently depending on their biological origin and they are classified into two groups: Entomophagous or macrobiological (predators and parasitoids) and Entomopathogens or microbiological (fungi, viruses, bacteria, nematodes). Predators, parasitoids, and entomopathogens form three distinct groups according to how they act on the target organism. Predatory arthropods (usually females and males) are characterized by predatory behavior, which involves searching and handling the prey, which they feed on immediately after the capture. After feeding, which can occur by eating body parts (in the case of chewing insects) or by sucking the hemolymph (in the case of sucking insects), the predator searches for the next victim, repeating this activity until it is satisfied. Thus, predatory arthropods require large amounts of preys to develop themselves.

Parasitoids (only females) search for their host, in which they lay one or more eggs, depending on the parasitoid species. In the host, eggs give rise to the larvae, which develop at the expense of the victim's body content. At the end of the juvenile phase, they emerge as adults leaving their host's cadaver. Therefore, parasitoids require a single host to complete their life cycle and are represented mainly by insects, which can parasitize different development stages of the host species.

Entomopathogens are microorganisms or invertebrates that cause disease in their hosts and include fungi, bacteria, viruses, and nematodes. Fungi infect its target hosts through reproductive structures called spores that germinate and penetrate the victim's body when in contact with its exoskeleton. The fungi grow and multiply in the host's cavity of the body, producing new reproductive structures that colonize the entire host cadaver. These structures, the spores, are responsible for spreading and infecting other organisms. Unlike fungi, bacteria and viruses require to be ingested by the host to cause an infection. Bacteria store toxic proteins as crystals, which are released in the victim's intestine, causing a generalized infection and the host's consequent death. Viruses make up a group of obligate intracellular parasites and use the host cell structure to replicate its genetic material. Nematodes are invertebrates associated with symbiotic bacteria. They generally penetrate in the host body through natural openings, such as the mouth, anus, and breathing holes (spiracles), and release the bacteria responsible for the victim's infection in the intestine. Thus, bacterial symbionts are the responsible for killing the host and allowing the nematode to feed on its cadaver.

The use of ecosystem services provided by biological agents is according with incentives to use sustainable practices for food production and certifications in cellulose, ethanol, and flower production. This demand has required the use of clean technologies to obtain products free of chemical residues, with desirable social and environmental returns. Factors such as resistance to insect pests and risks to humans and to other animals' health are also added, encouraging producers to use fewer chemicals and adopt more sustainable protection methods against pests (Mengistie et al., 2017). In floriculture, the perspective is no different since the sector looks forward to ending the problems arising from pesticide uses and preservation of the quality standard of the generated products (Bueno et al., 2016, Carvalho et al., 2019). Additionally, using biological agents can lead to considerable reductions in production costs and better prices with products free of chemical residues.

In this context, the integrated pest and disease management of ornamental plants has been increasingly used. In commercial crops of roses (Rosa spp.), lilies (Lilium spp.), spaths (Spathiphyllum spp.), begonias (Begonia spp.), and orchids (Orchidaceae), for example, a significant reduction in the application of pesticides has been achieved through integrated control strategies, such as biological agents (Bueno et al., 2016). In Spathiphyllum sp. crops, pests and diseases management carried out by a production system planning solved problems linked to the occurrence of fungus gnats, the most important pest of the 
crops (Carvalho et al., 2019). In surveys on formulations, based on Trichoderma, which is widely commercialized by the world, Bettiol et al. (2019a) present information on many of these products, which are used against diseases and in promoting the growth of several ornamental species.

In this paper, we aim to address the strategies to be used so that the natural enemies can promote population control of pests in general. We present the species of biological agents that are already available for commercialization aiming at the pests control in floriculture. We also present the technologies that have been used more recently to increase the appropriate use and efficiency of these agents in production systems.

\section{Brief history of Applied Biological Control}

The use of biological control of pests in Brazil is relatively recent. However, in a worldwide scenario, the use of living organisms to control pests in crops is ancient.

In the applied context, which involves anthropic action, biological control dates back to $1200 \mathrm{BC}$, when predatory ants (Oecophylla smaragdina Fabricius) (Hymenoptera: Formicidae) were used for insect pests management in citrus groves in China (Berti Filho and Macedo, 2010). The Chinese introduced $O$. smaragdina nests into their plantations to protect their crops against these harmful insects. Subsequently, in the $4^{\text {th }}$ to $6^{\text {th }}$ centuries, predatory ants were also used to control leaf-cutting ants in the Middle East. However, the first successful case of biological control occurred around 1890, using a predatory ladybug [Novius (= Rodolia) cardinalis Mulsant)] (Coleoptera: Coccinellidae) imported from Australia, to control a species of mealybug (Icerya purchasi Maskell) (Hemiptera: Monophlebidae), also with Australian origin, which was destroying citrus crops in California, USA (Caltagirone and Doutt, 1989). The first record of a pest control, using microorganisms, dates back to 1888 , with the spraying of the fungus Metarhizium anisopliae (Metch.) Sorokin (Hypocreales: Clavicipitaceae) to control a beetle (Cleonus punctiventris Germar) (Coleoptera: Curculionidae) in beet plantations in Russia (Lord, 2005).

In Brazil, the applied biological control started to have a greater expression from the 1970s. Among the most successful cases, the use of the parasitoid Cotesia flavipes (Cameron) (Hymenoptera: Braconidae) for the control of the sugarcane borer, Diatraea saccharalis (Fabricius) (Lepidoptera: Pyralidae) stands out. Nowadays, about 40\% of the areas cultivated with sugarcane in Brazil are treated with those wasps that parasitize the borer caterpillars (Parra and Coelho Jr, 2019). Trichogramma galloi Zucchi (Hymenoptera: Trichogrammatidae), a wasp that parasitizes the borer's eggs, is also used to control this pest in this same culture.

The use of the fungus $M$. anisopliae to control the spittlebug, Mahanarva fimbriolata (Stål) (Hemiptera: Cercopidae), also stands out in sugarcane crops. Currently, about half of the entire sugarcane-producing area uses this control strategy. Another successful example in Brazil is the use of the bacterium Bacillus thuringiensis (Berliner) (Bacillales: Bacillaceae) (Bt) for the control of Helicoverpa armigera (Hübner) (Lepidoptera: Noctuidae), an important pest in several crops.

In recent years, the effectiveness of these natural enemies for pests control has fostered commercial production of biological agents, mostly based in the use of microorganisms. The bacterium B. thuringiensis and fungi Beauveria bassiana (Bals.) Vuill (Ascomycota: Hypocreales) and M. anisopliae are the most used agents in Brazil among the biological products currently registered.

\section{Application of Biological Control in cultivated areas}

The mayor part of the occurrence pest outbreaks is due to imbalances in the populations of the species that inhabit the cultivated areas. One of the primary causes of such imbalances refers to the simplification of the environment, which, in most cases, is cultivated by a single plant species. Monocultures cause a reduction in the number and richness of natural enemy species, who leave the area in search of more favorable environments, where they will find abundant food resources. Thus, the complexity of the cultivated environment assumes relevance as it promotes the establishment of a great diversity of organisms (plants and insects), which naturally interact in different ways, maintaining their populations balance (Cassman and Wood, 2005).

The modification of a simplified cultivation to maintain and foster the diversity and the increase of natural enemy population of pests is called Conservative Biological Control. These modifications involve the intercropping and/or the introducing of appropriate botanical species that can be maintained in or around the main crop, whether annual or perennial. The increase in plant diversity aims to provide shelter and food (such as nectar, pollen, and honeydew) to the natural enemies. The conservation of strips of wild plants within the cultivation area, for example, provides the permanence of natural enemies that use other foods besides their preys (Venzon et al., 2019). The cowpea consortium in succession to corn favored the diversity and the abundance of predatory mites in Jatropha curcas (Cañarte et al., 2020). The flowering plants introduced in strips can also increase the herbivore population levels, which will be food resource to the natural enemies, benefiting them in periods of scarcity of pests in the crop since it ensures their survival, fertility, and longevity and its efficiency in the pest control. Coccinellid larvae and adults feed on aphids present in spontaneous plants in pepper crops, but adults are often observed in flowers and floral and extrafloral nectaries of aphid-free plants (Amaral et al., 2013).

The diversity of natural enemies was also affected by the anthropization of the cultivated areas, being lower in conventional farms and higher in agroecological management areas. According to Togni et al. (2018), the predation was identified as the main mortality factor of Bemisia tabaci (Gennadius) MEAM1 (Middle EastAsia Minor 1) (= biotype B) (Hemiptera: Aleyrodidae) 
nymphs, in all the types of farm management, except in the conventional ones. Moreover, the biological control resulting from the action of natural enemies was, in general, more significant in the most diversified farms and with less intensive management.

In addition to the local variables, an important factor to be considered is related to the landscape structure, i.e., the vegetation composition in the region, and not only in the cultivated area. Paredes et al. (2015) studied the potential effects that can arise from the interaction between the landscape and the adopted practices to promote the action of natural enemies. The authors identified the type of soil cover, composed of perennial vegetation, close to the primary crop, as a promising alternative for the conservative biological control.

Another way to explore the ecological services of the natural agents of biological control (predators, parasitoids, and entomopathogenic organisms) is to produce them in laboratories, in large amounts, to be released on the plantations. The production of natural enemies in a large scale, aiming at their release in the field, is named Augmentative Biological Control. This method has been implemented in modern pest management systems in several countries. Nowadays, many beneficial species are commonly grown by commercial insectaries and commercialized for use in pest population control in various types of crops.

Although there are usually many species of natural enemies associated with agricultural pests, these organisms must be studied before they are produced on a large scale in laboratories. In order to a natural enemy is considered a promising biological control agent, it must present characteristics such as ease of being massively reared, don't present negative interactions after release, such as intraguild or non-target organism predation, quickly locate the prey or host, cause a high mortality rate, and present climatic adaptation (Souza et al., 2019a).

Brazil, a country of continental dimensions, has enormous biological diversity. However, there is little knowledge about it. Although the volume of the carried out research to prospect new control agents has grown in recent years, the number of species used as bio-inputs is modest. Among the most used arthropods as biological products are several groups of insects and mites. The representatives of the orders Hymenoptera, Hemiptera, and Coleoptera stand out in the Insecta class, while predatory mites highlight in the Arachnida class. Among the hymenopterans, there are parasitoid wasps of the families Trichogrammatidae, Braconidae, and Platygastridae. The representatives of Hemiptera and Coleoptera are predators belonging to the families Anthocoridae and Coccinellidae. In addition to the predator group, there are four mite species from the families Phytoseiidae and Laelapidae. Among the entomopathogens, the fungi $B$. bassiana, M. anisopliae, Hirsutella thompsonii (Fischer) (Hypocreales: Ophiocordycipitaceae), and Paecilomyces fumosoroseus (Wize) Brown \& Smith (Deuteromycotina: Hyphomycetes) highlight. Among the bacteria, we highlight the $B$. thuringiensis due to its high insecticidal activity against a wide range of pest species, especially, lepidopterans and coleopterans. Regarding viruses, baculoviruses stand out for their high capacity for multiplication and high specificity, being the most documented and recognized among the groups of pathogenic viruses to insects, especially species of the order Lepidoptera, with relevant utility as biological control agents.

\section{Biological Agents available for commercialization in Brazil for releasing in ornamental plants}

Currently, there is a diversity of biotechnological alternatives available to be used in integration with other pests control strategies. If on the one hand, the market for insecticidal and fungicidal biological products is growing, on the other, there is still a gap regarding the control of weeds since there are no biological products registered so far.

In Brazil, investments in the prospecting and production of macro and microbiological agents have considerably increased in recent years, providing a bigger and bigger portfolio of commercial product options for controlling arthropods that cause damage to ornamental plants. Among the range of phytophagous species associated to floriculture, Lepidoptera caterpillars (Noctuidae), stink bugs (Pentatomidade), tetranychid mites, aphids, thrips, white flies, and mealybugs (Tables 1 and 2) stand out. Additional information about each control agent is presented below. 
Table 1. Macrobiological agents of interest to floriculture registered in Brazil and indications of use.

\begin{tabular}{|c|c|c|c|c|}
\hline Macrobiological Agent & Target-Pest & Target-Stage & Dose & $\begin{array}{c}\text { Number and season } \\
\text { of application }\end{array}$ \\
\hline \multicolumn{5}{|c|}{ Parasitoid } \\
\hline $\begin{array}{l}\text { Trichogramma } \\
\text { pretiosum }\end{array}$ & $\begin{array}{l}\text { Lepidoptera } \\
\text { Noctuidae }\end{array}$ & Eggs & $\begin{array}{l}100,000 \text { to } 750,000 \\
\text { adults/ha }\end{array}$ & $\begin{array}{l}\text { Variable for each target-pest } \\
\text { and crop }\end{array}$ \\
\hline Telenomus podisi & $\begin{array}{l}\text { Pentatomidae } \\
\text { Stinkbug }\end{array}$ & Eggs & $\begin{array}{l}48 \text { to } 96 \text { capsules } \\
\text { of sachets/ha } \\
\text { distributed in } \\
\text { equidistant points }\end{array}$ & $\begin{array}{l}\text { Two to three releases when } \\
\text { detecting the first adult } \\
\text { stinkbugs }\end{array}$ \\
\hline \multicolumn{5}{|c|}{ Predator } \\
\hline Neoseiulus californicus & $\begin{array}{l}\text { Spotted spider mite } \\
\text { (Tetranychus urticae) }\end{array}$ & All & $\begin{array}{l}4 \text { flasks/ha or } \\
20,000 \text { mites }\end{array}$ & $\begin{array}{l}\text { At the beginning of the } \\
\text { infestation, two releases every } \\
30 \text { days }\end{array}$ \\
\hline Phytoseiulus macropilis & $\begin{array}{l}\text { Spotted spider mite } \\
\qquad \text { (T. urticae) }\end{array}$ & All & $100,000 \mathrm{mites} / \mathrm{ha}$ & $\begin{array}{c}\text { At the beginning of the } \\
\text { infestation directed at the } \\
\text { outbreak and repeat every } 19 \\
\text { days }\end{array}$ \\
\hline Stratiolaelaps scimitus & $\begin{array}{l}\text { Fungus gnats (Bradysia } \\
\text { matogrossensis) }\end{array}$ & Larvae & $\begin{array}{l}\text { Azaleas: } 200 \text { mites/ } \\
\mathrm{m}^{2} \text { or } 20 \mathrm{~mL} \text { of } \\
\text { the commercial } \\
\text { product }\end{array}$ & $\begin{array}{l}\text { One application after planting } \\
\text { the seedlings }\end{array}$ \\
\hline $\begin{array}{l}\text { Cryptolaemus } \\
\text { montrouzieri }\end{array}$ & $\begin{array}{c}\text { Pink mealybug } \\
\text { (Maconellicoccus } \\
\text { hirsutus) }\end{array}$ & All & $\begin{array}{c}5,000 \text { mealybugs/ } \\
\text { ha }\end{array}$ & $\begin{array}{l}\text { Two to three times per year and } \\
\text { a break of two months between } \\
\text { the applications }\end{array}$ \\
\hline Orius insidiosus & $\begin{array}{l}\text { Tripes (Frankliniella } \\
\text { occidentalis) }\end{array}$ & Adults and nymphs & $\begin{array}{l}\text { Chrysanthemum: } \\
1.5 \text { to } 2 \text { predators/ } \\
\mathrm{m}^{2} \text {, gerbera: } \\
19.2 \text { predators/ } \\
\mathrm{m}^{2} \text {, or } 19.2 \times 10^{4} \\
\text { predators } / \mathrm{ha}\end{array}$ & $\begin{array}{l}\text { Use at the beginning of the } \\
\text { infestation and reuse every } 15 \\
\text { days }\end{array}$ \\
\hline Amblyseius tamatavensis & $\begin{array}{l}\text { Whitefly (Bemisia } \\
\text { tabaci) }\end{array}$ & Eggs and nymphs & $\begin{array}{l}50 \text { to } 200 \text { alive } \\
\text { predators mites/ha }\end{array}$ & $\begin{array}{l}\text { At the beginning of the } \\
\text { infestation with } 14 \text { to } 21 \text {-day } \\
\text { breaks }\end{array}$ \\
\hline
\end{tabular}

Source: Agrofit (2020) 
Table 2. Microbiological agents of interest to floriculture registered in Brazil and indications of use.

\begin{tabular}{|c|c|c|c|c|}
\hline Microbiological Agent & Target-Pest & Target-Stage & Dose & $\begin{array}{l}\text { Volume of the } \\
\text { solution }\end{array}$ \\
\hline \multicolumn{5}{|c|}{ Bacterium } \\
\hline Bacillus thuringiensis & Larvae (Lepidoptera) & Small larvae & $\begin{array}{l}\text { Varies with the } \\
\text { species }\end{array}$ & Varies with the crop \\
\hline \multicolumn{5}{|c|}{ Fungi } \\
\hline Beauveria bassiana & $\begin{array}{c}\text { Spotted spider mite } \\
\text { (T. urticae), Green scale (Coccus } \\
\text { viridis), Whitefly (B. tabaci), Aphid } \\
\text { (Aphis gossypii), Tripes (F. occidentalis } \\
\text { and Thrips tabaci) }\end{array}$ & All & $\begin{array}{l}\text { Varies with the } \\
\text { species }\end{array}$ & Varies with the crop \\
\hline Hirsutella thompsonii & Spotted spider mite (T. urticae) & All & 1.5 to $2.5 \mathrm{~L} / \mathrm{ha}$ & Varies with the crop \\
\hline Paecilomyces fumoroseus & Whitefly (B. tabaci) & All & 1.5 to $2 \mathrm{~L} / \mathrm{ha}$ & 100 to $200 \mathrm{~L} / \mathrm{ha}$ \\
\hline $\begin{array}{c}\text { Beauveria bassiana }+ \\
\text { Metarhizium anisopliae }\end{array}$ & Whitefly (B. tabaci) & All & 100 to $400 \mathrm{~g} / \mathrm{ha}$ & $200 \mathrm{~L} / \mathrm{ha}$ \\
\hline \multicolumn{5}{|c|}{ Virus } \\
\hline Baculovirus Helicoverpa & Larvae (Helicoverpa armigera) & $\begin{array}{l}\text { Larvae up to } \\
\text { the } 3^{\text {rd }} \text { instar }\end{array}$ & 50 to $200 \mathrm{~mL} / \mathrm{ha}$ & 100 to $150 \mathrm{~L} / \mathrm{ha}$ \\
\hline Baculovirus Spodoptera & Larvae (Spodoptera frugiperda) & $\begin{array}{l}\text { Larvae up to } \\
\text { the } 3^{\text {rd }} \text { instar }\end{array}$ & $50 \mathrm{~g} / \mathrm{ha}$ & Varies with the crop \\
\hline Baculovirus Chrysodeixis & Larvae (Chrysodeixis includens) & $\begin{array}{l}\text { Larvae up to } \\
\text { the } 3^{\text {rd }} \text { instar }\end{array}$ & 50 to $200 \mathrm{~mL} / \mathrm{ha}$ & $100 \mathrm{~L} / \mathrm{ha}$ \\
\hline
\end{tabular}

Source: Agrofit (2020)

\section{Macrobiology agents or entomophagous}

\footnotetext{
Trichogramma pretiosum Riley (Hymenoptera: Trichogrammatidae)

Parasitic wasps of the Trichogramma genus are widely used in crops against Lepidoptera caterpillars (Oliveira et al., 2020a). Wasps are released repeatedly into the crop during the cultivation period (Oliveira et al., 2020b). The host species has a high influence on the quality of the parasitoids that develop within. The size of the egg is significant. If they are too small, there will be no parasitism, whilst larger eggs are more prone to super-parasitism (the parasitism of the same egg by more than one female).

In most cases, the majority of the Trichogramma eggs are laid during the first two days after the adults' emergence (Malais and Ravensberg, 2003). After being parasitized, the host egg is 'marked' both inside and out, so that it will not be parasitized again. The eggs of most species of moths, especially those of the Noctuidae family, can be parasitized, as they are generally ideally suited to the development of Trichogramma species. Problems only arise if moths of a specific species cover their eggs with hairs or wing scales or deposit the eggs in multiple layers (Oliveira et al., 2020a). The parasitic wasp searches through the plant from the bottom up and narrows its search area whenever a suitable egg is found (Malais and Ravensberg, 2003).
}

Telenomus podisi Ashmead (Hymenoptera: Platygastridae)

Telenomus podisi stands out due to its ability to control several stink bug species of economic importance at the egg stage, thus avoiding any injuries to the plants in the field (Queiroz et al., 2018). This species is a quasigregarious egg parasitoid (a solitary species that develops in aggregated hosts) of several stink bugs, including both herbivorous and predatory species (Koppel et al., 2009). Older parasitoids (ten days old) showed higher parasitism than younger ones (one day old), regardless of the offered host (Queiroz et al., 2019). However, older parasitoids are usually less selective, lowering their quality threshold below which hosts are rejected (Cingolani et al., 2014). The ability to parasitize up to five-day-old host eggs and to keep their oocytes viable even after host deprivation, thereby maintaining parasitism capacity and the period of fertility, is clearly an advantage when using $T$. podisi in biological control for stink bug management (Queiroz et al., 2019).

Neoseiulus californicus (McGregor) (Acari: Phytoseiidae)

Neoseiulus californicus is a predatory omnivore or a generalist mite. It can feed on a broader range of foods and may not be so constrained. $N$. californicus is one of the principal natural enemies of tetranychid mites in several countries and promotes the efficient control of those mites in several crops (Marafeli et al., 2014). The efficiency of the 
biological control of the spotted spider mite pest, Tetranychus urticae Koch (Acari: Tetranychidae) might be improved if $N$. californicus could be retained in the crop in the absence of the primary pest, i.e., possibly by provisioning a supplementary food such as floral pollen. However, phytoseiid performance can vary greatly among pollen sources (Vacacela Ajila et al., 2018). Although $N$. californicus took longer to suppress the T. urticae population compared to Phytoseiulus macropilis (Banks) (Acari: Phytoseiidae) (Souza-Pimentel et al., 2017), it persisted longer on the plants after preys were reduced to low densities (Vacacela Ajila et al., 2018). Thus, the success of $N$. californicus is partially due to a number of factors, including its feeding habits and its ability to suppress T. urticae under varying weather conditions (Akyazi et al., 2019).

Phytoseiulus macropilis (Banks) (Acari: Phytoseiidae)

Phytoseiulus macropilis is a predator mite of T. urticae, considered as exclusively carnivorous or specialist, and restricted to warm climates (Coombs et al., 2014). This predator has desirable attributes for biological control programs spider mite, such as a shorter life cycle compared with T. urticae (Fadini et al., 2004), a high predation rate in greenhouse, and an ability to control spider mite populations, even when released at high population densities of the pest (Oliveira et al., 2009). Despite a high capacity to reduce pest populations (Souza-Pimentel et al., 2017), the exclusively carnivorous predators persist poorly in the environment at low prey densities. However, this specialist predator suppressed the population of $T$. urticae faster than $N$. californicus, leading to the extinction of both pest and predator populations three weeks after the predators were released (Vacacela Ajila et al., 2018). Furthermore, $P$. macropilis did not seem affected by the low humidity and high temperatures recorded in the greenhouse (Oliveira et al., 2009; Gigon et al., 2016).

Stratiolaelaps scimitus (Womersley) (Acari: Laelapidae)

Stratiolaelaps scimitus, a polyphagous soil-inhabiting predatory mite, has shown great potential against several pest species, including the prepupae or pupae of Frankliniella occidentalis (Pergande) (Thysanoptera: Thripidae) and the larvae of dark-winged fungus gnats, Bradysia matogrossensis (Lane) (Diptera: Sciaridae) in mushroom farms, nurseries, and greenhouses (Wen et al., 2019; Yoon et al., 2020). The longevity of $S$. scimitus feeding on the pupae of $F$. occidentalis is superior to 70 days, and the combined use of $S$. scimitus and $B$. bassiana fungi may be able to assure the stability of $F$. occidentalis control (Zhang et al., 2020). However, the thermal stress during release, $37^{\circ} \mathrm{C}$ for 4 hours, suffered by S. scimitius, could reduce mites' survival (Gobbi et al., 2020).

Cryptolaemus montrouzieri Mulsant (Coleoptera: Coccinellidae)

This ladybird of Australian origin is employed against mealybugs. All moving stages of $C$. montrouzieri prey on mealybugs, seizing their preys and consuming them entirely (Kairo et al., 2013). Adult ladybirds and young larvae prefer the eggs and young pests' larvae, while older larvae feed on all stages of mealybugs equally (Mani, 2018). Adult ladybirds are good fliers and can disperse over a large area in search of prey. Although $C$. montrouzieri prefers mealybugs, this species is known to be a polyphagous predator. Sometimes other insects related to mealybugs are eaten, such as soft scales or aphids. However, this beetle is most effective in controlling large populations of Pseudococcidae family mealybugs. The larvae of the last third and fourth instars are the most voracious, consuming up to 30 mealybugs per day (Malais and Ravensberg, 2003).

Orius insidiosus (Say) (Hemiptera: Anthocoridae)

The predatory bugs of the Anthocoridae family (flower bugs), mainly Orius spp., are frequently found in glasshouses. Members of this family are polyphagous predatory insects feeding on thrips, aphids, mites, and other small arthropods (Lundgren, 2009). They can attack all stages, including adults (mainly of soft-bodied species), larvae, nymphs, and eggs. Pollen is also an important food source for many flower-dwelling anthocorids, and its availability on a crop can improve the maintenance of these natural enemies in the area (Labbé et al., 2018). Most species can occasionally feed on plant sap, but without causing real damage to the plant. There is a high degree of correlation between prey density and the size of predatory bug populations. Adult predatory bugs are mainly found in flowers, with the immature stages usually occurring on leaves. Predatory mites and bugs can coexist, and although they often compete for food, sometimes, they can complement each other, because each one performs better under different conditions and in different parts of the crop (Malais and Ravensberg, 2003).

Amblyseius tamatavensis Blommers (Acari: Phytoseiidae)

Currently, Amblyseius tamatavensis has been marketed as a control agent of $B$. tabaci, considering the high consumption of whitefly eggs and the possibility of rearing this phytoseiid on factitious preys. The promising results obtained by Cavalcante et al. (2017), releasing 15 adult $A$. tamatavensis females per plant, suggest the high potential of this species to control B. tabaci in pepper plants. The relatively low tolerance of phytoseiids to starvation is one of the main factors that affects the success of biological control with these predators. Therefore, the pollen used as a food supplement for generalist predators can accelerate their establishment and improve their performance, preventing cannibalism that could occur when preys are scarce (Goleva and Zebitz, 2013). Barbosa et al. (2019) demonstrated that A. tamatavensis is suitable for the biological control of $B$. tabaci on cotton, bean, potato, melon, and tomato plants. However, significant differences in egg consumption on tomato and melon leaves indicate that further studies must be carried out to determine the appropriate dose and release methods on these plants to ensure the predator's efficiency. 


\section{Microbiology agents or entomopathogenic}

Bacteria

Bacillus thuringiensis or $\mathrm{Bt}$ is a biocontrol agent for defoliating pests used worldwide (Plata-Rueda et al., 2020). Individual strains are specific to a small group of targetinsects without effects on animals and the environment (Schnepf et al., 2018). Bt is a gram-positive spore-forming bacterium with entomopathogenic properties. Bt produces crystalline or "Cry" inclusions in the sporulation, called $\delta$-endotoxins, biosynthesized during the second phase of the growth cycle. In this cycle, the Cry proteins are converted into active toxins upon ingestion insects (Castro et al., 2019). In addition to direct mortality, Bt can induce sublethal effects on growth and reproduction (Huang et al., 2018).

\section{Fungi}

Over 110 insecticides, based on entomopathogenic fungi (mycoinsecticides), have been registered in Brazil until 2020 with most of them using M. anisopliae or $B$. bassiana.

Beauveria bassiana infects at least ten species of thrips (Butt and Brownbridge, 1997). Cryptic insects like F. occidentalis that live in flowers do not die immediately after infection, creating the opportunity for further horizontal transmission of the inoculum to different developmental stages (Membang et al., 2020). This horizontal transmission contributes to high combined mortality and mycosis that varies among the isolated ones. Foliar applications of $B$. bassiana have proven effective in reducing populations of $F$. occidentalis larvae and adults (Ludwig and Oetting, 2002). Several research findings demonstrated that $B$. bassiana exhibited insecticidal activity against Plutella xylostella L. (Lepidoptera: Plutellidae) (Xia et al., 2013), Spodoptera exigua (Hübner) (Lepidoptera: Noctuidae) (Wraight et al., 2010), Spodoptera frugiperda (J.E. Smith) (Lepidoptera: Noctuidae) (Cruz-Avalos et al., 2019), B. tabaci (Mascarin et al., 2013), and H. armigera (DouroKpindou et al., 2012).

Metarhizium anisopliae has been used mainly based on its high genetic variability, immense host range, and easy industrial-scale production, formulation, and application (Ashraf et al., 2017). The successful infection process, confirmed with sporulation on dead insects, is a secondary source of inoculum generally involved in autodissemination and epizootic occurrence, which strengthens disease outbreaks in the field and, consequently, reduces host populations and limits insect pest outbreaks (Vega et al., 2007).

\section{Virus}

Baculoviruses infect insects, especially caterpillars, and are considered sophisticated pathogens used for biological control (Valicente, 2019). Baculovirus-based bioinsecticides have high specificity, virulence, ability to persist in the environment, and compatibility with natural enemies (parasitoids, pathogens, and predators) and chemical insecticides (Costa et al., 2019). The natural dispersion of baculovirus is possible due to its ability to exist in a dormant state during different insect stages. This fact occurs when viruses are ingested at sublethal concentrations (virus replication is non-existent), failing to cause disease signs. The latent virus can be activated and initiate an infection or can be transmitted to the host offspring (Kukan, 1999).

\section{Technologies to improve the Biological Control}

Technologies have contributed to great advances in improving the obtaining, characterization, viability, survival, and performance of biological control agents. Some of these are briefly presented below.

Molecular Biology: its applicability is related to the more accurate taxonomic identification, mainly of cryptic species and strains of microorganisms, in addition to the characterization of trophic networks, especially predators, essential for the selection of potential biological control agents (Paula et al., 2016; Peterson et al., 2018). The sequencing of the new generation has enabled the knowledge of complete genomes of various insect species, including natural enemies, which makes it possible to identify transcriptomes that allow the identification of transcribed genes and how these genes affect the organism's relationships with environmental conditions, life stages, and interactions with other organisms (Pisani et al., 2013). Another technology on the rise is CRISPR (CluStered Regularly Interspaced Short Palindromic Repeats), which allows specific changes to be made in the genomic DNA of target organisms. It has already been used in the genome editing of fungi used as biological control agents (Kistler et al., 2015). The interfering RNA (RNAi) technology is based on the silencing of insect's genes that involves the transformation, for example, of an entomopathogenic fungus with a double-stranded RNA (dsRNA) molecule of whitefly (B. tabaci). The transgenic entomopathogenic fungus increases the mortality of infected whitefly nymphs by blocking its target gene, carried by the recombinant fungus (Chen et al., 2015).

Nanotechnology: is related to the preparation of biopesticides, allowing the stabilization of products by protecting the released control agents in the environment, with controlled release and precise doses (Manjunatha et al., 2016). A typical example would be the nanoencapsulation of entomopathogenic fungi with improved viability, release, and protection against biotic and abiotic stresses, besides the environmental safety aspects (Adzmi et al., 2012).

Agriculture 4.0: by using artificial intelligence tools, the producer can use Software to visualize their properties from a distance, monitor and control in real-time the production process, identifying areas with pest infestation, and optimizing the decision-makings. Thus, the appropriate biological agent for each target-pest can be used at the 
ideal time, at the most susceptibility place, and in exact amounts. The release of control agents became possible for large areas by using drones, unmanned vehicles used in the mapping, management, and control of pest-arthropods. This kind of equipment detects the areas with injuries caused by insects, allowing, for example, precise releases of the control agents in the infested areas and with the exact dosage (Sylvester et al., 2018).

Mixture of bioagents from different taxonomic groups: use of different strategies, such as "Entomovectoring", where bees are used both for pollination and for the dispersion of fungal or bacterial formulations to control pathogens and insects that attack flowers. The "attract and kill" formulations control only insects with cryptic habits. In this case, the insects fall into the traps containing entomopathogenic fungi conidia or attractive pheromone formulations. Bettiol et al. (2019b) believe that the mixture between the plant disease and pest biological control agents composes another possibility of use, citing as an example, formulations containing Trichoderma mixed with Metarhizium or Trichoderma with Beauveria.

\section{Final Considerations}

Several species of insects and other arthropods, besides phytopathogenic agents, associated with flowers and ornamental plant cultivations can cause significant economic losses. Sustainable management strategies that integrate better ecological processes must be part of the production process to obtain the high quality required by consumers. Biological pest control has been a target of great attention as a sustainable method for pest control.

Besides the sustainability aspect, biological control agents have attracted the attention of producers, companies, and researches since the number of registered chemical insecticides is restricted and these inputs are limited to the control of few pests that attack ornamental plants. Additionally, many insecticides are ineffective due to their cryptic habit, common in several species that take shelter in flowers or other parts of the plant that are protected against the spraying. Furthermore, besides the high standard of flower and foliage quality desired, the exemption of chemical residues in ornamental plants is an important requisite to achieve new markets.

Thus, researches on biological control have significantly expanded in recent decades and demonstrated the potential use of macrobiological and microbiological agents. The advance in the use of biological control is showed by the recent increase in the number of companies that sell products of biological origin. Methods for using these beneficial organisms are continuously developed or improved, and other species are explored and investigated. Much investigation is still necessary for that new species to be added to the bioagents portfolio, especially in the Brazilian floriculture.

\section{References}

ADZMI, F.; MEON, S.; MUSA, M.H.; YUSUF, N.A. Preparation, characterization and viability of encapsulated Trichoderma harzianum UPM40 in alginatemontmorillonite clay. Journal of Microencapsulation, v.29, n.3, p.205-210, 2012. https://doi.org/10.3109/02652 048.2012 .659286 .

AGROFIT. Ministério da Agricultura, Pecuária e Abastecimento. Agrofit, Consulta aberta. Available at: http://agrofit.agricultura.gov.br/agrofit_cons/principal_ agrofit_cons. Access on: Dec 17, 2020.

AKYAZI, R.; LIBURD, O.E. Biological control of the twospotted spider mite (Trombidiformes: Tetranychidae) with the predatory mite Neoseiulus californicus (Mesotigmata: Phytoseiidae) in blackberries. Florida Entomologist, v.102, n.2, p.373-381, 2019. https://doi. org/10.1653/024.102.0217.

AMARAL, D.S.S.L.; VENZON, M.; DUARTE, M.V.A.; SOUSA, F.F.; PALLINI, A.; HARWOOD, J.D. Non-crop vegetation associated with chili pepper agroecosystems promote the abundance and survival of aphid predators. Biological Control, v.64, p.338-346, 2013. https://doi. org/10.1016/j.biocontrol.2012.12.006.

ASHRAF, M.; FAROOQ, M.; SHAKEEL, M.; DIN, N.; HUSSAIN, S.; SAEED, N.; SHAKEEL, Q.; RAJPUT, N.A. Influence of entomopathogenic fungus, Metarhizium anisopliae, alone and in combination with diatomaceous earth and thiamethoxam on mortality, progeny production, mycosis, and sporulation of the stored grain insect pests. Environmental Science and Pollution Research, v.24, n.36, p.28165-28174, 2017. https://doi.org/10.1007/s11356-017-0383-6.

BARBOSA, M.F.; POLETTI, M.; POLETTI, E.C. Functional response of Amblyseius tamatavensis Blommers (Mesostigmata: Phytoseiidae) to eggs of Bemisia tabaci (Gennadius) (Hemiptera: Aleyrodidae) on five host plants. Biological Control, v.138, p.104030, 2019. https://doi. org/10.1016/j.biocontrol.2019.104030.

BERTI FILHO, E.; MACEDO, L.P.M. Fundamentos de controle biológico de insetos-praga. Natal: IFRN Editora, 2010. 108p.

BETTIOL, W.; SILVA, J.C.; CASTRO, M.L.M.P. Uso atual e perspectivas do Trichoderma no Brasil. In: MEYER, M.C.; MAZARO, S.M; SILVA, J.C. Trichoderma: uso na agricultura. Brasília: Embrapa, 2019a. p.21-43.

BETTIOL, W.; PINTO, Z.V.; SILVA, J.C.; FORNER, C.; FARIA, M.R.; PACIFICO, M.G.; COSTA, L.S.A.S. Produtos comerciais à base de Trichoderma. In: MEYER, M.C.; MAZARO, S.M; SILVA, J.C. Trichoderma: uso na agricultura. Brasília: Embrapa, 2019b. p.45-160. 
BUENO, V.H.P.; LENTEREN, J.C. VAN; BETTIOL, W.; RAVENSBERG, W. Controle biológico em cultivo protegido. In: HALFELD-VIEIRA, B.A.; MARINHOPRADO, J.S.; NECHET, K.L.; MORANDI, M.A.B.; BETTIOL, W. Defensivos agrícolas naturais: uso e perspectivas. Brasília: Embrapa Meio Ambiente, 2016. p.457-504.

BUTT, T.M.; BROWNBRIDGE, M. Fungal pathogens of thrips. In: LEWIS, T. (ed.) Thrips as crop pests CABI International. Wallingford, Oxon: CABI, 1997. p.399-433.

CALTAGIRONE, L.E.; DOUTT, R.L. The history of the Vedalia beetle importation to California and its impact on the development of biological control. Annual Review of Entomology, v.34, n.1, p.1-16, 1989. https://doi. org/10.1146/annurev.en.34.010189.000245.

CAÑARTE, E.; SARMENTO, R.A.; ERASMO, E.A.L.; PALLINI, A.; VENZON, M.; PINTO, I.O.; PEDRONETO, M. Contributions of intercropping systems for diversity and abundance of mite community on Jatropha curcas. BioControl, v.65, p.305-312, 2020. https://doi. org/10.1007/s10526-020-10009-y.

CARVALHO, L.M.; SOUZA, B.; SOUSA, A.L.V. Biological control in major crops, forests, pasture, weeds and plant diseases in the neotropical region: Ornamental Plants. In: SOUZA, B., VÁZQUEZ, L.L.; MARUCCI, R.C. Natural enemies of insect pests in Neotropical Agroecosystems: biological control and functional biodiversity. Switzerland: Springer, 2019. p.355-368.

CASSMAN, K.G.; WOOD, S. Cultivated Systems. In: HASSAN, R.; SCHOLES, R.; ASH, N. Ecosystems and Human Well-being: Current State and Trends. Washington: Island Press, 2005. p.745-794.v.1.

CASTRO, B.M.; MARTINEZ, L.C.; BARBOSA, S.G.; SERRÃO, J.E.; WILCKEN, C.F.; SOARES, M.A.; DA SILVA, A.A.; DE CARVALHO, A.G.; ZANUNCIO, J.C. Toxicity and cytopathology mediated by Bacillus thuringiensis in the midgut of Anticarsia gemmatalis (Lepidoptera: Noctuidae). Scientific Reports, v.9, n.1, p.110, 2019. https://doi.org/10.1038/s41598-019-43074-0.

CAVAlCANTE, A.C.; MANDRO, M.E.; PAES, E.R. DE MORAES, G.J. Amblyseius tamatavensis Blommers (Acari: Phytoseiidae) a candidate for biological control of Bemisia tabaci (Gennadius) biotype B (Hemiptera: Aleyrodidae) in Brazil. International Journal of Acarology, v.43, n.1, p.1015, 2017. https://doi.org/10.1080/01647954.2016.1225816.

CHEN, X.; LI, L.; HU, Q.; ZHANG, B.; WU, W.; JIN, F.; JIANG, J. Expression of dsRNA in recombinant Isaria fumosorosea strain targets the TLR7 gene in Bemisia tabaci. BMC Biotechnology, v.15, n.64, p.1-8, 2015. https://doi. org/10.1186/s12896-015-0170-8.
CINGOLANI, M.F.; GRECO, N.M.; LILJESTHRÖM, G.G. Effect of Telenomus podisi, Trissolcus urichi, and Trissolcus basalis (Hymenoptera: Platygastridae) age on attack of Piezodorus guildinii (Hemiptera: Pentatomidae) eggs. Environmental Entomology, v.43, n.2, p.377-383, 2014. https://doi.org/10.1603/EN13250.

COOMBS, M.R.; BALE, J.S. Thermal biology of the spider mite predator Phytoseiulus macropilis. BioControl, v.59, n.2, p.205-217, 2014. https://doi.org/10.1007/s10526014-9559-x.

COSTA, V.H.; SOARES, M.A.; DIMATE, F.A.; SÁ, V.G.; ZANUNCIO, J.C.; VALICENTE, F.H. Genetic identification and biological characterization of Baculovirus isolated from Helicoverpa armigera (Lepidoptera: Noctuidae) in Brazil. Florida Entomologist, v.102, n.1, p.59-64, 2019. https://doi.org/10.1653/024.102.0109.

CRUZ-AVALOS, A.M.; BIVIÁN-HERNÁNDEZ, M.D.; IBARRA, J.E.; DEL RINCÓN-CASTRO, M.C. High virulence of Mexican entomopathogenic fungi against Fall Armyworm, (Lepidoptera: Noctuidae). Journal of Economic Entomology, v.112, n.1, p.99-107, 2019. https://doi.org/10.1093/jee/toy343.

DOURO-KPINDOU, O.; DJEGUI, D.; GLITHO, I.A.; TAMO, M. Sensitivity of Helicoverpa armigera (Hubner) (Lepidoptera: Noctuidea) to the Entomopathogenic fungi, Metarhizium anisopliae and Beauveria bassiana in laboratory. ARPN Journal of Agricultural and Biological Science, v.7, n.12, p.1007-1015, 2012.

FADINI, M.A.; LEMOS, W.P.; PALLINI, A.; VENZON, M.; MOURÃO, S.A. Herbivoria de Tetranychus urticae Koch (Acari: Tetranychidae) induz defesa direta em morangueiro? Neotropical Entomology, v.33, n.3, p.293-297, 2004. https://doi.org/10.1590/S1519$566 \times 2004000300003$.

GIGON, V.; CAMPS, C.L.E.; CORFF, J. Biological control of Tetranychus urticae by Phytoseiulus macropilis and Macrolophus pygmaeus in tomato greenhouses. Experimental and Applied Acarology, v.8, n.1, p.55-70, 2016. https://doi.org/10.1007/s10493-015-9976-2.

GOBBI, P.C.; DUARTE, J.L.; SILVA, L.R.; NAVA, D.E.; FIALHO, G.S.; CUNHA, U.S.; DUARTE, A.D. Effects of thermal shock on the survival and reproduction of Stratiolaelaps scimitus (Mesostigmata: Laelapidae). Experimental and Applied Acarology, v.82, n.4, p.493501, 2020. https://doi.org/10.1007/s10493-020-00570-7.

GOLEVA, I.; ZEBITZ, C.P. Suitability of different pollen as alternative food for the predatory mite Amblyseius swirskii (Acari, Phytoseiidae). Experimental and Applied Acarology, v.61, n.3, p.259-283, 2013. https://doi. org/10.1007/s10493-013-9700-z. 
HUANG, S.; LI, X.; LI, G.; JIN, D. Effect of Bacillus thuringiensis CAB109 on the growth, development, and generation mortality of Spodoptera exigua (Hübner) (Lepidoptera: noctuidea). Egyptian Journal of Biological Pest Control, v.28, n.19, 2018. https://doi.org/10.1186/ s41938-017-0023-y.

KAIRO, M.T.; PARAISO, O.; GAUTAM, R.D.; PETERKIN, D.D. Cryptolaemus montrouzieri (Mulsant) (Coccinellidae: Scymninae): a review of biology, ecology, and use in biological control with particular reference to potential impact on non-target organisms. Cab Reviews: Perspectives in Agriculture, Veterinary Science, Nutrition and Natural Resources, v.8, n.5, p.1-20, 2013. https://doi.org/10.1079/PAVSNNR20138005.

KISTLER, K.E.; VOSSHALL, L.B. MATTHEWS B. J. Genome engineering with CRISPR-Cas9 in the mosquito Aedes aegypti. Cell Reports, v.11, n.1, p.51-60, 2015. https://doi.org/10.1016/j.celrep.2015.03.009.

KOPPEL, A.L.; HERBERT, J.R. DA; KUHAR, T.P.; KAMMINGA, K. Survey of stink bug (Hemiptera: Pentatomidae) egg parasitoids in wheat, soybean, and vegetable crops in southeast Virginia. Environmental Entomology, v.38, n.2, p.375-379, 2009. https://doi. org/10.1603/022.038.0209.

KUKAN, B. Vertical transmission of nucleopolyhedrovirus in insects. Journal of Invertebrate Pathology, v.74, n.2, p.103-111, 1999.

LABBÉ, R.M.; GAGNIER, D.; KOSTIC, A.; SHIPP, L. The function of supplemental foods for improved crop establishment of generalist predators Orius insidiosus and Dicyphus hesperus. Scientific Reports, v.8, n.1, p.17790, 2018. https://doi.org/10.1038/s41598-018-36100-0.

LORD, J.C. From Metchnikoff to Monsanto and beyond: the path of microbial control. Journal of Invertebrate Pathology, v.89, n.1, p.19-29, 2005. https://doi. org/10.1016/j.jip.2005.04.006.

LUDWIG, S.W.; OETTING, R.D. Efficacy of Beauveria bassiana plus insect attractants for enhanced control of Frankliniella occidentalis (Thysanoptera: Thripidae). The Florida Entomologist, v.85, n.1, p.270-272, 2002.

LUNDGREN, J.G. Relationships of natural enemies and non-prey foods. Berlin: Springer Science \& Business Media, 2009. 470p.

MALAIS, M.H.; RAVENSBERG, W.J. Knowing and recognizing: the biology of glasshouse pests and their natural enemies. Netherlands: Koppert BV, 2003. 288p.
MANI, M. Hundred and sixty years of Australian lady bird beetle Cryptolaemus montrouzieri Mulsant - a global view. Biocontrol Science and Technology, v.28, n.10, p.938952, 2018. https://doi.org/10.1080/09583157.2018.14870 29.

MANJUNATHA, S.B.; BIRADAR, D.P.; ALADAKATTI, Y.R. Nanotechnology and its applications in agriculture: a review. Journal of Pharmaceutical Sciences, v.29, n.1, p.1-13, 2016.

MARAFELI, P.P.; REIS, P.R.; SILVEIRA, E.D.; SOUZAPIMENTEL, G.C.; TOLEDO, M.D. Life history of Neoseiulus californicus (McGregor, 1954) (Acari: Phytoseiidae) fed with castor bean (Ricinus communis L.) pollen in laboratory conditions. Brazilian Journal of Biology, v.74, n.3, p.691-697, 2014. https://doi. org/10.1590/bjb.2014.0079.

MASCARIN, G.M.; KOBORI, N.N.; QUINTELA, E.D.; DELALIBERA, J.R.I. The virulence of entomopathogenic fungi against Bemisia tabaci biotype B (Hemiptera: Aleyrodidae) and their conidial production using solid substrate fermentation. Biological Control, v.66, n.3, p.20918, 2013. https://doi.org/10.1016/j.biocontrol.2013.05.001.

MEMBANG, G.; AMBANG, Z.; MAHOT, H.C.; KUATE, A.F.; FIABOE, K.K.M.; HANNA, R. Cosmopolites sordidus (Germar) susceptibility to indigenous Cameroonian Beauveria bassiana (Bals.) Vuill. and Metarhizium anisopliae (Metsch.) isolates. Journal of Applied Entomology, v.144, n.6, p.468-480, 2020. https:// doi.org/10.1111/jen.12757.

MENGISTIE, B.T.; MOL, A.P.J.; OOSTERVEER, P. Governance of agro-pesticide through private environmental and social standards in the global cut flower chain from Ethiopia. Ambio, v.46, n.7, p.797-811, 2017. https://doi.org/10.1007/s13280-017-0914-X.

OLIVEIRA, H.; FADINI, M.A.; VENZON, M.; REZENDE, D.; REZENDE, F.; PALLINI, A. Evaluation of the predatory mite Phytoseiulus macropilis (Acari: Phytoseiidae) as a biological control agent of the twospotted spider mite on strawberry plants under greenhouse conditions. Experimental and Applied Acarology, v.47, n.4, p.275-283, 2009. https://doi.org/10.1007/s10493-0089217-z.

OLIVEIRA, R.C.; PASTORI, P.L.; BARBOSA, M.G.; PEREIRA, F.F.; MELO, J.W.; ANDRÉ, T.P. Dispersal of Trichogramma pretiosum Riley, 1879 (Hymenoptera: Trichogrammatidae) in cabbage, cucumber, and sweet corn. Anais da Academia Brasileira de Ciências, v.92, Suppl. 1, e20190412, 2020b. https://doi.org/10.1590/00013765202020190412. 
OLIVEIRA, R.C.; PASTORI, P.L.; COUTINHO, C.R.; JUVENAL, S.O.; AGUIAR, C.V. Natural parasitism of Trichogramma pretiosum (Hymenoptera: Trichogrammatidae) in Neoleucinodes elegantalis (Lepidoptera: Crambidae) eggs on tomato (Solanales: Solanaceae) in the Northeast region, Brazil. Brazilian Journal of Biology, v.80, n.2, p.474-475, 2020a. https://doi.org/10.1590/1519-6984.206676.

PAREDES, D.; CAYUELA, L.; GURR, G.M.; CAMPOS, $M$. Is ground cover vegetation an effective biological control enhancement strategy against olive pests? PLoS One, v.10, n.2, e0117265, 2015. https://doi.org/10.1371/ journal.pone.0117265.

PARRA, J.R.P.; COELHO JÚNIOR, A. Applied biological control in Brazil: from laboratory assays to field application. Journal of Insect Science, v.19, n.5, p.1-6, 2019. https:// doi.org/10.1093/jisesa/iey112.

PAULA, D.P.; LINARD, B.; CRAMPTON-PLATT, A.; SRIVATHSAN, A.; TIMMERMANS, M.J.; SUJII, E.R.; PIRES, C.S.; SOUZA, L.M.; ANDOW, D.A.; VOGLER, A.P. Uncovering trophic interactions in arthropod predators through DNA shotgun-sequencing of gut contents. PLoS One, v.11, n.9, e0161841, 2016. https://doi.org/10.1371/ journal.pone.0161841.

PETERSON, J.A.; BURKNESS, E.C.; HARWOOD, J.D.; HUTCHISON, W.D. Molecular gut-content analysis reveals high frequency of Helicoverpa zea (Lepidoptera: Noctuidae) consumption by Orius insidiosus (Hemiptera: Anthocoridae) in sweet corn. Biological Control, v.121, p.17, 2018. https://doi.org/10.1016/j.biocontrol.2018.02.006.

PISANI, D.; CARTON, R.; CAMPBELL, L.I.; AKANNI, W.A.; MULVILLE, E.; ROTA-STABELLI, O. An overview of arthropod genomics, mitogenomics, and the evolutionary origins of the arthropod proteome. In: MINELLI, A.; BOXSHALL, G.; FUSCO, G. (eds.) Arthropod Biology and Evolution. Berlin: Springer, 2013. p.41-61. https:// doi.org/10.1007/978-3-642-36160-9_3.

PLATA-RUEDA, A.; QUINTERO, H.A.; SERRÃO, J.E.; MARTÍNEZ, L.C. Insecticidal activity of Bacillus thuringiensis strains on the nettle caterpillar, Euprosterna elaeasa (Lepidoptera: Limacodidae). Insects, v.11, n.5, p.1-10, 2020. https://doi.org/10.3390/insects 11050310.

QUEIROZ, A.P.; FAVETTI, B.M.; HAYASHIDA, R.; GRANDE, M.L.; NEIVA, M.M.; PANIZZI, A.R.; BUENO, A.D. Effect of the ages of parasitoid and host eggs on Telenomus podisi (Hymenoptera: Platygastridae) parasitism. Neotropical Entomology, v.48, n.6, p.974982, 2019. https://doi.org/10.1007/s13744-019-00724-2.
QUEIROZ, A.P.; TAGUTI, E.A.; BUENO, A.F.; GRANDE, M.L.; COSTA, C.O. Host preferences of Telenomus podisi (Hymenoptera: Scelionidae): parasitism on eggs of Dichelops melacanthus, Euschistus heros, and Podisus nigrispinus (Hemiptera: Pentatomidae). Neotropical Entomology, v.47, p.543-552, 2018. https:// doi.org/10.1007/s13744-017-0564-5.

SCHNEPF, E.; CRICKMORE, N.V.; VAN RIE, J.; LERECLUS, D.; BAUM, J.; FEITELSON, J.; ZEIGLER, D.R.; DEAN, D. Bacillus thuringiensis and its pesticidal crystal proteins. Microbiology and Molecular Biology Reviews, v.62, n.3, p.775-806, 1998.

SOUZA, B.; SANTOS-CIVIDANES, T.M. dos; CIVIDANES, F.J.; SOUSA, A.L.V. Bioecology of natural enemies used in biological control in the Neotropical Region: predators insects. In: SOUZA, B.; VAZQUEZ, L.L.; MARUCCI, R.C. Bioecology of natural enemies used in biological control in the Neotropical Region: biological control and functional biodiversity. Switzerland: Springer, 2019a. p.73-87.

SOUZA, B.; VAZQUEZ, L.L.; MARUCCI, R.C. Bioecology of natural enemies used in biological control in the Neotropical Region: biological control and functional biodiversity. Switzerland: Springer, 2019b. p. 107-112.

SOUZA-PIMENTEL, G.C.; REIS, P.R.; BONATTO, C.R.; ALVES, J.P.; SIQUEIRA, M.F. Reproductive parameters of Phytoseiulus macropilis (Banks) fed with Tetranychus urticae Koch (Acari: Phytoseiidae, Tetranychidae) in laboratory. Brazilian Journal of Biology, v.77, n.1, p.162169, 2017. https://doi.org/10.1590/1519-6984.13115.

SYLVESTER, G.; RAMBALDI, G.; GUERIN, D.; WISNIEWSKI, A.; KHAN, N.I.; VEALE, J.; XIAO, M. E-agriculture in action: drones for agriculture. Bangkok: Food and Agriculture Organization of the United Nations and International Telecommunication Union, 2018.

TOGNI, P.H.B.; VENZON, M.; SOUZA, L.M.; SANTOS, J.P.C.R.; SUJII, E.R. Biodiversity provides whitefly biological control based on farm management. Journal of Pest Science, v.92, p.393-403, 2019. https://doi. org/10.1007/s10340-018-1021-x.

VACACELA AJILA, H.E.; COLARES, F.; LEMOS, F.; MARQUES, P.H.; FRANKLIN, E.C.; SANTOS DO VALE, W.; OLIVEIRA, E.E.; VENZON, M.; PALLINI, A. Supplementary food for Neoseiulus californicus boosts biological control of Tetranychus urticae on strawberry. Pest Management Science, v.75, n.7, p.1986-1992, 2019. https://doi.org/10.1002/ps.5312. 
VALICENTE, F.H. Entomopathogenic Viruses. In: SOUZA, B.; VÁZQUEZ, L.L.; MARUCCI, R.C. Natural enemies of insect Pests in Neotropical Agroecosystems: Biological Control and functional biodiversity. Switzerland: Springer, 2019. p. 137-150.

VEGA, F.E.; DOWD, P.F.; LACEY, L.A.; PELL, J.K.; JACKSON, D.M.; KLEIN, M.G. Dissemination of beneficial microbial agents by insects. In: LAWRENCE, A.L.; HARRY, K.K. (eds.). Field manual of techniques in invertebrate pathology. Dordrecht: Springer, 2007. p. 153-177.

VENZON, M.; AMARAL, D.S.S.L.; TOGNI, P.H.B.; CHIGUACHI, J.A.M. Interactions of natural enemies with non-cultivated plants. In: SOUZA, B., VÁZQUEZ, L.L.; MARUCCI, R.C. Natural enemies of insect pests in Neotropical Agroecosystems: Biological Control and functional biodiversity. Switzerland: Springer, 2019. p.15-26.

WEN, M.F.; CHI, H.; LIAN, Y.X.; ZHENG, Y.H.; FAN, Q.H.; YOU, M.S. Population characteristics of Macrocheles glaber (Acari: Macrochelidae) and Stratiolaelaps scimitus (Acari: Laelapidae) reared on a mushroom fly Coboldia fuscipes (Diptera: Scatopsidae). Insect Science, v.26, n.2, p.322-332, 2019. https://doi.org/10.1111/1744-7917.12511.
WRAIGHT, S.P.; RAMOS, M.E.; AVERY, P.B.; JARONSKI, S.T.; VANDENBERG, J.D. Comparative virulence of Beauveria bassiana isolates against lepidopteran pests of vegetable crops. Journal of Invertebrate Pathology, v.103, n.3, p.186-199, 2010. https://doi.org/10.1016/j.jip.2010.01.001.

XIA, J.; HUANG, Z.; HU, Q. Histopathological study of Plutella xylostella infected by three entomopathogenic fungal species. Advances in Entomology, v.1, n.2, p.1519, 2013. http://dx.doi.org/10.4236/ae.2013.120042013.

YOON, J.B.; CHOI, S.K.; CHO, I.S.; KWON, T.R.; YANG, C.Y.; SEO, M.H.; YOON, J.Y. Epidemiology of tomato spotted wilt virus in Chrysanthemum morifolium in South Korea and its management using a soil-dwelling predatory mite (Stratiolaelaps scimitus) and essential oils. Virus Research, v.289, e198128, 2020. https://doi.org/10.1016/j. virusres.2020.198128.

ZHANG, X.; WU, S.; REITZ, S.R.; GAO, Y. Simultaneous application of entomopathogenic Beauveria bassiana granules and predatory mites Stratiolaelaps scimitus for control of western flower thrips, Frankliniella occidentalis. Journal of Pest Science, v.94, n.1, p.1-9, 2020. https://doi. org/10.1007/s10340-020-01227-5. 